\title{
Remittance Behaviour of Intra-EU Migrants - Evidence from Hungary
}

\author{
László Kajdi, Anna Sára Ligeti
}

\begin{abstract}
After the eastern expansion of the European Union (EU), a large number of emigrants left their home countries to work in economically better developed western member states. Hungary followed this EU emigration trend with a certain time lag. However, the rising number of emigrants caused structural problems in the domestic labour market. A comprehensive examination of intra-EU remittances as one of the major determinants of migration has been outside the scope of recent research activity. The data from the Hungarian Microcensus survey and the first Hungarian household survey focusing on the topic of remittances can provide a valuable case study of intra-EU private transfer flows.

The aims of this study are twofold. On the one hand we intend to provide empirical evidence for the major factors that determine remittance propensity by calculating probit regressions. On the other hand, OLS regressions are calculated in order to introduce variables which are associated with money transfers. These results are interpreted within the theoretical framework of the New Economics of Labour Migration (NELM) to identify the underlying motivations for remittances. The most important findings are that older men with vocational school education have the highest remittance propensity, and the likelihood of sending private support is higher among short-term migrants. As the key factors, the income of the sender person is positively associated with the sum of money flows, while the income of the receiving household is negatively associated. Within the theoretical framework of NELM, these results favour the dominance of altruistic motives, since supporting the household members who remain behind seems to be the major driving force. However, when intentions of returning home are considered in the models, it seems that self-interest might also play a role as a driver of remittances. Within this study, the main focus was on the characteristics of the senders, meaning that a possible field of future research could be an examination of these questions from the perspective of remittance receiver households.
\end{abstract}

Keywords: Labour-market · Remittances · European Union · Migration policy 


\section{Introduction}

As globalisation increases and geographical distances can now be bridged easily as a result of the dramatic expansion of travel infrastructure, the economic, social and cultural effects of international migration are the focus of attention in several countries. Resulting money flows sent by migrants - remittances - are also gaining increasing attention in research projects. Remittances are more stable over time compared to Foreign Direct Investments (FDI) or foreign financial aid (Official Development Assistance - ODA) and can have a significant general impact on poverty (Acosta et. al. 2008; Koc/Onan 2006; Koechlin/Leon 2007; Ratha/Mohapatra 2010; Sirkeci et al. 2012) by contributing to investment and development in the countries of origin (Durand et al. 1996; Leon-Ledesma/Piracha 2004). However, the phenomenon of remittances is much more controversial, and some researchers tend to focus rather on the potential which lies in these money flows instead of their actual benefits (e.g. de Haas 2012). Several studies emphasize that, besides the aforementioned advantages, remittances can increase the volume of emigration as well as the level of inequality within the population in migrants' countries of origin through the selection characteristics of emigration. This means that those households which are able to cover the high initial costs of sending a family member abroad will receive additional income from this source, while the relative deprivation of the poorer households which cannot afford emigration will tend to grow (Massey 1988; Stark/ Taylor 1989; Taylor 1999).

According to Eurostat, ${ }^{1}$ the number of citizens from eastern member states in economically better developed western countries rose dramatically from 1.5 million in 2004 to 8.1 million in 2017 in Europe since the start of the expansion of the Union in 2004. So far, the volume of emigration has been the primary centre of public and academic attention in eastern EU member states, and economic motivational factors such as remittances have been somewhat neglected. In Hungary the increase in emigration lagged behind that of other countries in the region and started to grow significantly only after 2011 (Hárs 2016). Several projects were launched to obtain a clearer picture of this, one of the most notable being the international SEEMIGproject ${ }^{2}$ led by the Hungarian Central Statistical Office (HCSO) and the Hungarian Demographic Research Institute (HDRI). The results of the project survey (Blaskó 2014) showed that approximately 350,000 Hungarians were living abroad permanently in 2013, and they were younger and better educated than the average person in Hungary (Blaskó/Gödri 2014, 2016), nonetheless the educational composition dif-

1 We used data from the Eurostat database (downloaded: 13 October 2018) and we considered the number of citizens from Eastern EU countries (Bulgaria, Czech Republic, Estonia, Hungary, Latvia, Lithuania, Poland, Romania, Slovenia and Slovakia) in certain Western EEA countries (Austria, Belgium, Denmark, Finland, Germany, Iceland, Ireland, Greece, Spain, France, Italy, Liechtenstein, Luxembourg, the Netherlands, Norway, Portugal, Sweden, Switzerland and the United Kingdom).

2 "SEEMIG - Managing Migration in South East Europe" as part of the South East Europe Programme. 
fers significantly among the main target countries. People who are relatively young and more highly qualified leave the country for the United Kingdom, while those leaving for Austria and Germany are mainly single men with a vocational educational background (Hárs/Simon 2016). There is also differentiation concerning the length of stay: Hungarians moving to the UK usually live there for longer periods, while emigrants in Austria and Germany stay less than a year, in general. Estimations based on recent ESS mirror statistics ${ }^{3}$ and a Microcensus survey showed that approximately 460,000 Hungarian citizens resided abroad in 2016 (Dickmann/Ligeti 2018).

The aforementioned studies also revealed that recent emigration caused issues in several fields in Hungary, e.g. labour shortages in certain economic sectors (Hárs/Simon 2017), and this might be the case in other Eastern European countries as well. Financial flows like remittances sent by emigrants could also represent an even more ambiguous field of migration studies due to the difficulties of collecting sensitive income-related information which is comprehensive and realistic. In order to overcome these challenges, a two-stage household data collection process was performed in Hungary concerning remittances, the results of which might yield important conclusions for other countries in the region as well. The international migration panel of the large-sample Microcensus 2016, followed by a remittancespecific household survey, was possibly a unique attempt in the region to obtain a clear picture of financial flows of intra-EU migrants.

Our intention in this study is to contribute to the academic research on remittances within the European Union by providing evidence for the determining factors of remittance propensity of Hungarians abroad and the sum of money flows. On the basis of the results we also try to identify the motives behind private transfers using the theoretical framework of the New Economics of Labour Migration (NELM). Since previous data collections showed that there are major differences between those who leave the country for more than a year (younger and more highly qualified people usually move to the United Kingdom) and temporary emigrants (mainly older men with vocational school education leave for Austria and Germany), we further examine differences between short- and long-term emigrants. This is also important in the light of the findings of several studies described below which concluded that remittance habits change over time. Although only cross-sectional data were at our disposal, the examination of temporary and permanent emigrants allowed us to address some of the changes in remittance habits. The surveys analysed provide comprehensive data on international migration and remittance flows, therefore such an examination can also serve as a background for further research not just in Hungary, but also across all Eastern European EU member states.

After presenting the main theoretical concepts and literature concerning remittances, we briefly introduce the characteristics of the data sets used and the meth-

3 Based on immigration data of the member states of the European Statistical System (Switzerland, Norway, Liechtenstein, Iceland, Turkey and EU-28 countries except Cyprus, Malta and Spain). 
ods applied. This description is followed by a presentation of the main results, while the final chapter draws conclusions with a focus on public policy implications.

\section{Literature overview}

The role of remittances as a factor for inducing and sustaining emigration, as well as their contribution to the development of migrants' countries of origin has been a matter of discussions for decades. Among the major theoretical concepts of migration, the topic might be expressed most strongly in the NELM on the micro (household) level (Stark/Bloom 1985). The NELM argues that the migration decision is part of a family strategy to minimise risks and raise and secure income, while remittances help to set in motion a "development dynamic" in migrants' countries of origin (Taylor 1999).

Most theoretical debates on determinants of remittances are based on the opposing concepts of altruistic vs. self-interest motives. In their fundamental work, Lucas/Stark (1985) placed remittance motivations in a range from pure altruism to pure self-interest. Between these two distinct positions lies the motivation of tempered altruism or enlightened self-interest, where remittances are one element in a self-enforcing arrangement between migrants and the household members who have remained behind. In these contractual arrangements it is the sending family which usually covers the initial costs of migration and daily expenses in the host country during the job-seeking period, but later, remittances are expected from the migrant in compensation for this initial support (Massey 1990; Piché 2013; Stark/ Lucas 1988).

The analysis of remittance effects within the process of migration has so far mainly focussed on money flows to less developed countries (e.g. Licuanan et al. 2015; Orozco et al. 2005), and several studies have attempted to identify the determinant factors of remittance propensity or the sum of transfers. Some researchers followed a macro-level concept, mainly using Balance of Payments (BoP) data, while the other approach examines the topic based on micro-level household surveys.

On the macro-level, studies found evidence for the relationship between remittances and macro-determinants like government expenditures (Hathroubi/Aloui 2016), the economic output of the country sending remittance (Akkoyun/u/Kholodilin 2008) or receiving it (Vargas-Silva 2008). As for remittances to Hungary, recent studies analysed World Bank (Kajdi 2016) or Eurostat Balance of Payments (BoP) data (Csortos/Kóczián 2017). Based on the latter data source, temporary migrants who left Hungary for less than a year had an income of 3.2 billion euros in 2018 ("Compensation of employees" in the BoP), while those who migrated permanently (i.e. for at least one year, "Current personal transfers" in BoP) sent more than 900 million euros in 2018 (Eurostat 2019). However, it is important to note that data in the "Compensation of employees" row in the BoP only refer to potential remittances, but it does not mean that they are actually transferred to household members who remain behind, since this row captures gross incomes (Csortos/Kóczián 2017). These numbers therefore also include taxes, consumption and savings, for 
example, besides the amounts sent to the country of origin, which can result in bias when using them for analysing remittance flows. In the case of Hungary, the number of short-term migrants exceeds the number of those who left the country for more than a year, meaning that a significant proportion of remittance-related BoP data (i.e. "Compensation of employees") refers to the gross income of these people instead of the money they send home. Another issue with macro-data is that mirror statistics are also used in the calculation of BoP data in order to estimate the number of Hungarian emigrants. However, since large numbers of Hungarian nationals born outside Hungary also possess Hungarian citizenship (650,000 persons by 2015 according to HCSO 2017), it is hard to capture only those migrants who left Hungary instead of other - usually neighbouring - countries. This means that some of the registered Hungarian citizens emigrating to Germany, for instance, might in reality come from countries other than Hungary, and thus presumably do not send their transfers to Hungary.

On the micro level, some surveys intended to identify the background motivations for remittances. Cox et al. (1998) tested the two competing hypotheses of altruistic and exchange-type motivations for private income transfers. Results showed a positive relationship between recipient income and transfer amounts, which supports mainly exchange-type motivations. Nevertheless, evidence from a longitudinal Canadian (Unheim/Rowlands 2012) and a Chinese (Cai 2003) survey showed that, alongside other factors such as age, the income of the sender also has a positive relationship with the sum of money flows in line with altruistic motivations. In contrast to the aforementioned studies, Holst/Schrooten (2006), based on data from Germany, found no relationship between remittance propensity and income, while the correspondence between the amount of the transfer and the level of income proved to be significant only for low-income individuals. A possible explanation for the diverging results in the relationship between remittances and income is that it is not linear over time (Cox et al. 2004), i.e. migrants' attitude towards supporting the household members who remain can change during the years spent abroad. Besides altruism, purchasing insurance through remittances can also be an important driving factor of migrants' behaviour, as Mexican data, for instance, prove (Amuedo-Dorantes/Pozo 2006). This is especially important for those who are not registered employees, thus their income risks are higher.

Other studies aim to reveal the determining factors behind the amount of private transfers. The difficulties in obtaining a clear picture are highlighted by Bollard et al. (2009), for instance, who examined 14 surveys from 11 OECD countries, but found no clear connection between migrants' educational levels and their remittance propensity. However, a strong positive relationship was identified between the educational level and the money sent home. Analysis of Italian SILC survey data showed that most migrants transfer financial aid to household members in the country of origin, which indicates the importance of remittances within the migration process. Nevertheless, Eastern European workers tend to send less home than migrants from third countries outside of EU. The results further confirmed the hypothesis that the probability of not supporting the family in the country of origin is twice as high in the case of migrants with higher education (Busetta et al. 2016). This is in line 
with descriptive data from a survey on Macedonian migrants which show that the remittance propensity is highest among those performing blue-collar work and with a secondary education (Roberts et al. 2008). Evidence from surveys on emigrants from Ukraine (Ambrosetti et al. 2014) and Moldova (Pinger 2010) suggest that remittance propensity and the amount of transfers is higher in the case of older migrants. The latter study also showed that those with a higher educational level and with an intention to return in the near future tend to send more money.

The role of the time spent abroad is also highlighted by Czaika/Spray (2013), who found evidence for a positive relationship between private transfers and age, education and male migrants, but emphasized the nonlinear remittance trajectory over time. Studies revealed that short-term migrants tend to send higher amounts ( $\mathrm{Cai}$ 2003; Simkova/Langhamrova 2015), which is also in accordance with the results of Dustmann/Mestres (2010) who presented evidence for the higher remittance propensity among short-term migrants.

Concerning Hungary, the SEEMIG survey was among the first micro-level attempts to measure remittance propensity. It showed that almost one-third of Hungarian emigrants regularly support their household members in the country of origin (Blaskó/Gödri 2016). Nevertheless, before 2017 no specific survey was performed aimed at gaining a detailed insight into the personal financial transfers from other countries to Hungary.

Based on the results of previous international researches, we intend to test the following hypotheses. As Unheim/Rowlands (2012) highlighted, most existing evidence supports a positive relationship between the migrant's income and the remittance sum, and thus we expect the same to apply in the case of Hungaryl. Cox et al. (2004) found a negative association between the amount of private transfers and the receiving households' income, although this relationship is not linear, which is likely to be the case in Hungary as well. On the basis of these results we assume that altruistic motivations dominate in remittances from Hungarian emigrants i.e. in the case of senders who have altruistic motivations, the relationship between the amount of the remittance and the sender's income is positive, while a negative association can be identified with the receiving households' income (Hypothesis 1). Regarding the determinants of remittances, the studies highlighted suggest that younger migrants with a higher educational level tend to have a lower remittance propensity and send less (Hypothesis 2.). This may be the case in Hungary, too, due to the different socio-demographic background of Hungarian emigrant groups. As described in the next chapter, Hungarian emigrants can be roughly divided into two main categories: older blue-collar workers moving to Austria and Germany for a short period in order to gain higher income, and younger, better qualified people leaving Hungary for longer periods, mainly to the UK. Based on the experiences presented in the international literature and the descriptive data of Hungarian emigrants we also expect short-term migrants to remit more (Hypothesis 3 ), thus we calculate separate models for temporary and permanent emigrants. 


\section{Data and methods}

Previous analyses showed evidence of the advantages of using surveys in the field of international migration (Brown et al. 2014; Fawcett/Arnold 1987; Gibson/McKenzie 2017), and in the present study we use the data from two Hungarian household data collections: the Microcensus and the Family transfers survey. The Microcensus survey was carried out by the Hungarian Central Statistical Office (HCSO) between 1 October and 8 November 2016. The main purpose of microcensuses - to update population data between two censuses - has become less significant in many countries since traditional census surveys have been replaced with data from administrative sources. Similar to the Census in 2011, the Microcensus 2016 was also prescribed by law, and participation by all household members at selected addresses was mandatory. A special feature of the Microcensus 2016 was that the sample size was larger than ever, covering approximately 10 percent of households, which meant a total of 440,000 addresses in 2,148 localities, and a total number of 840,000 personal questionnaires. Furthermore, five supplementary questionnaires were added, one of which covered the topic of international migration. In addition to the usual Microcensus questionnaires, each respondent was asked to complete one of the five different supplementary questionnaires on a voluntary basis. The supplementary questionnaire on international migration was filled in by a total of 41,000 respondents. The questions referred to different migrant groups, i.e. respondents were asked about their future intentions to leave the country, former experiences abroad as well as household members currently living abroad. In the case of respondents currently residing abroad or with former migratory experience, a question $^{4}$ was included concerning remittance propensity.

To complement Microcensus data, in 2017 May the Central Bank of Hungary organised a specific household survey (entitled "Family transfers"). The survey was carried out for the first time in Hungary, with the purpose of obtaining detailed data on the socioeconomic background of remittances. The data was collected by HCSO, with the survey covering the reference period of 2016 and a sample of 3,000 addresses. It is representative among private households in Hungary, and provides information on the receiving households, on the frequency of money flows, and on the emigrants sending these transfers. The questions also cover nonfinancial personal transfers (e.g. sending goods like electronic devices or food).

With regard to definitions, the design of both the Microcensus and the Family transfers survey permit analysis of the data based on the residence of the sender, according to the usual residence concept: the sender is considered to be resident in Hungary if the duration of foreign residence is temporary (i.e. less than one year spent abroad), and non-resident if emigration is permanent (i.e. lasts for at least one year). This categorisation is in line with the European regulations concerning

4 "While you were abroad, did you provide economic support for your family members in Hungary? / Does [the household member living abroad] provide economic support for his/her family members in Hungary?" 
population statistics ${ }^{5}$ as well as with BoP rules (IMF 2009). The latter condition is important to ensure that survey results can be compared to current macro data on remittances.

The Heckman selection method (Heckman 1976) was used to identify the determining factors of remittance behaviour and to resolve the selection bias problem. First, data of the Microcensus survey were used to capture the main effects of remittance propensity among Hungarian emigrants with probit regressions. Then, inverse Mills ratios ${ }^{6}$ were calculated from the results of probit regressions and were incorporated into the linear regression (OLS) models of the Family transfers survey in order to measure the most significant variables for the sum of the money transfers.

\section{$4 \quad$ Results}

\subsection{Descriptive statistics}

According to the Microcensus survey, 306,000 Hungarian citizens lived abroad in 2016 during the time of the data collection. Since entire households which were abroad at this time were not included in the sample, the actual emigration stock number is presumably higher. In addition to this, 378,000 people in Hungary had short or long-term migration experiences in the past 16 years. However, there are overlaps between the categories of short- and long-term migrants, and between current emigrants and those with migratory experience, therefore the total reference population is less than 684,000 .

The results reflecting the composition of Hungarian emigrants and return migrants based on the Microcensus are in line with earlier research findings. Emigrants are on average younger than the Hungarian population, and men as well as college/ university graduates are somewhat overrepresented. Concerning the major target regions, Hungarian emigrants are highly concentrated in three European countries (Germany, the United Kingdom and Austria) with 69 percent residing there, while only 8 percent live outside the European Economic Area (EEA). However, there are fundamental differences between Hungarians emigrating to these three countries.

5 Regulation (EC) 862/2007 of the European Parliament and of the Council on Community statistics on migration and international protection and repealing Council Regulation (EEC) No $311 / 76$ on the compilation of statistics on foreign workers. Similar to the Census of 2011, the Microcensus also took the concept of usual residence as its base, i.e. those staying abroad for more than one year were not considered part of the Hungarian population, and their data were not registered in the basic questionnaires. When analysing the emigration stock, it is necessary to collect information on those staying abroad for more than one year. Accordingly, the international migration supplementary survey collected information about these and former household members as well.

6 Inverse Mills ratio: this is the ratio of the probability density function to the cumulative distribution function of a distribution. It is often applied to handle selection bias in regression analysis. Selection bias arises when a data sample is not a random draw from the population that it is intended to represent. 
Among those living in Germany, there is a higher share of men, older age groups, and people with lower educational attainment levels, while Hungarians in the United Kingdom have typically finished secondary or tertiary education. As for the length of foreign residence, Hungarians are more likely to migrate to Germany or Austria for short periods, and to the United Kingdom or other countries for longer periods. Most Hungarians abroad (82 percent) moved for occupational reasons, and 60 percent of those who work are employed in three main occupational areas: commerce and services, industry and construction, and occupations requiring no qualifications. In the case of other countries, the main purpose of moving, according to descriptive statistics, is to study, and the share of women and emigrants with a college/university degree is higher.

The Microcensus results show that 31 percent of Hungarian citizens living abroad provided economic support to their Hungarian household members during their most recent stay abroad, which is in line with the results of the previous SEEMIG study on Hungarian emigrants (Blaskó/Gödri 2016). Almost half of those who were living abroad temporarily (for less than 1 year), and 30 percent of those who were residing permanently (for at least 1 year) in a foreign country at the time of the survey, sent home remittances. Among people with short-term (up to 1 year) migratory experiences since 2000, 29 percent provided financial support while living abroad, while 21 percent of those with long-term migratory experience (of at least 1 year) did so. These proportions are higher among migrants with lower educational attainment (elementary or vocational school), industrial workers, men, older age groups and those residing in Germany or Austria.

The weighted descriptive results of the "Family transfers survey" (Kajdi 2018) indicated that 1.6 percent (i.e. 67,548 in exact numbers) of private households in Hungary received financial support from abroad. The mean income of short-term emigrants is slightly lower compared to those who left the country for more than a year. This income difference was also apparent in the households left behind in the two groups (Table 1). Nevertheless, the mean amount sent by temporary emigrants is higher than the remittances sent by the long-term emigrants. A total of 72,240 sender persons were identified, which means that approximately 20 percent of the total 350,000 migrants (Blaskó/Gödri 2016) according to SEEMIG estimates, and 23 percent of the 306,000 persons living abroad captured by the Microcensus sent a remittance to Hungarian relatives. This ratio is lower compared to that of the results from the Microcensus, which is presumably attributable to two reasons. On the one hand, the "Family transfers survey" had a much smaller sample size, which can hamper attempts to obtain sufficient coverage. On the other hand, the nonresponse rate was larger due to the highly sensitive nature of the topic. Within the Microcensus, only one question was asked on this topic: whether the household receives remittance from abroad. The Family transfers survey, by contrast, was much more detailed. Information was asked for on the income of the household, but also on the exact amount of private transfers from abroad and the income of the sender person. Since these data are sensitive for private households, a lower response rate and coverage could have been anticipated in this survey compared to the Microcensus. 
Tab. 1: Descriptive statistics of incomes and remittances from the Family transfers survey

\begin{tabular}{lcrrrr}
\hline Variable & Observations & Mean & SD & Min & \multicolumn{1}{c}{ Max } \\
\hline Income per capita of the & & & & & \\
receiving household & 65,812 & 319.3 & 242.4 & 19.3 & $4,232.8$ \\
$\quad$ short-term emigrants & 33,019 & 306.4 & 266.8 & 19.3 & $4,232.8$ \\
$\quad$ long-term emigrants & 32,793 & 332.3 & 214.2 & 31.7 & $2,539.7$ \\
Income of the sender person & 72,240 & $11,462.2$ & $6,031.7$ & 0.0 & $525,471.4$ \\
$\quad$ short-term emigrants & 36,289 & $10,802.0$ & $3,555.6$ & 0.0 & $525,471.4$ \\
long-term emigrants & 35,951 & $12,141.1$ & $7,809.5$ & 0.0 & $220,952.4$ \\
Remittance per sender & 72,240 & $1,787.1$ & $3,615.9$ & 3.2 & $46,031.7$ \\
$\quad$ short-term emigrants & 36,289 & $2,067.9$ & $3,764.2$ & 3.2 & $46,031.7$ \\
$\quad$ long-term emigrants & 35,951 & $1,498.8$ & $3,433.2$ & 3.8 & $31,174.6$ \\
\hline
\end{tabular}

Note: Exchange rate HUF/EUR 315

Source: Family transfers survey 2017

The socio-demographic characteristics of senders are in accordance with the results of both previous Hungarian and some other studies in Central Europe (e.g. Roberts et al. 2008). The data has also revealed that mainly children supporting their elderly parents, which is similar to the results obtained, for example, by Ambrosetti et al. (2014). Concerning the sum of financial support from migrants, respondents reported approximately 125 million euros in transfers to relatives in Hungary, compared to a total of approximately 4,200 million euros in BoP. The most important reason for the deviation is the difference in the definitions applied for micro and macro data, i.e. BoP data contain taxes, consumption and also savings, therefore these data cannot be compared directly. It should also be noted that the distribution of the relevant data (household and sender income, amount of remittances received) appears realistic (close to log-normal distribution based on graphical analysis) in the survey, which strengthens their reliability. However, the potential for undercoverage and response bias cannot be excluded when surveying sensitive income data, as described above. In addition to this, Hungarian nationals who obtained Hungarian citizenship (mainly in Romania and Ukraine) might be a further source of minor differences as it was introduced above at BoP data. In the two surveys used, only those remittances which are actually sent to Hungary are captured, whereas some of the volume in the BoP might be transferred to other countries (like Romania or Ukraine) instead of Hungary. The descriptive data imply that emigrants in the United Kingdom tend to send less than those in Austria or Germany, which might be attributable to the different characteristics of these populations. While in the UK, mainly younger and more highly educated persons reside for a longer term, in Austria and Germany it is typically older men with a vocational school education. 
During the analysis of remittance behaviour, probit regressions were first calculated in order to identify the determinants of remittance propensity among Hungarian citizens working abroad. Our main objective was to identify which characteristics of Hungarians living abroad are significant with regard to whether the person supports the household in Hungary or not. However, it is important that only the sending of the remittance was examined at this stage, irrespective of the sum of the transfer.

The migration module of the 2016 Microcensus was used for this purpose, in which respondents were asked (among other things) whether they supported their household members in Hungary financially from abroad. Five categories were identified for the regressions in accordance with the structure of the Microcensus survey (Table 2):

- Subgroup "A": persons who had at least one year's (long-term) migratory experience, but had already returned to Hungary by the time of the survey.

- Subgroup "B": persons who had migration experience of less than one year (short-term migrants) since 2000, but had already returned to Hungary by the time of the survey.

- Subgroup " $\mathrm{C}$ ": persons who were temporarily (less than one year) abroad at the time of the survey.

- Subgroup " $\mathrm{D}$ ": persons who were permanently (at least for one year) abroad at the time of the survey.

- Subgroup "Total": all data in one dataset on respondents from categories " $A$ " to " $D$ ". The number of respondents $(N)$, however, is not the total of the previous categories, since persons can have both short- and long-term migratory experience. In the "Total" category only the most recent experience of each respondent was considered.

The distinction within the short- and long-term categories was partly a technical requirement based on the structure of the survey and the types of questionnaire. However, prior analysis of the Microcensus data showed significant differences between the current emigrants (subgroup " $\mathrm{C}$ " and " $\mathrm{D}$ ") and the return migrants (subgroup " $\mathrm{A}$ " and " $\mathrm{B}$ ") regarding most socio-economic characteristics (Dickmann/ Ligeti 2018). For instance, while return migrants were more likely to have migration experience outside the three main destination countries (such as the USA), recent emigration mostly tends towards Germany, the UK and Austria. In the groups of return emigrants, the ratio of those who have completed tertiary education exceeds that of those currently residing abroad by more than 10 percent, and the ratio of those who left Hungary for educational purposes is also higher among return migrants. The ratio of those who worked in a position which is not commensurate with their qualifications or educational level (on the basis of self-assessment by respondents) was also higher in the groups of return migrants, which could imply the increased establishment of migrational networks in recent years, and that it is easier for current emigrants to find an appropriate occupation. Another difference is the share of the foreign-born population (defining Hungarian citizens who were born in neighbouring countries) among the subgroups, which is higher in group " $\mathrm{A}$ ". 
Tab. 2: Distribution of migrants in the different categories of the Microcensus

\begin{tabular}{lccc}
\hline Subgroup & $\begin{array}{c}\text { Number } \\
\text { of respondents }\end{array}$ & $\begin{array}{c}\text { Weighted } \\
\text { number }\end{array}$ & $\begin{array}{c}\text { Proportion of } \\
\text { respondents remitting } \\
\text { in \% }\end{array}$ \\
\hline A (long-term migratory & 11,400 & 416,090 & 21 \\
experience) & & & 29 \\
B (short-term migratory & 8,789 & 338,922 & 49 \\
experience) & 1,176 & 45,276 & 30 \\
C (short-term emigrants) & 3,544 & 157,969 & 31 \\
D (long-term emigrants) & 13,124 & 517,078 & \\
Total & & & \\
\hline
\end{tabular}

Source: Microcensus 2016

As these deviations prove, the dynamics of emigration from Hungary showed significant changes both in volume as well as in structure in recent years (Hárs 2016), making it important to distinguish between current emigrants and those who have already returned, and to examine them separately in addition to the total emigrant "pool". There are also significant differences in long-term and short-term migration: short-term emigration from Hungary is more likely to be characterised as the labour migration of older male industrial and construction workers to Germany or Austria, and accordingly they are expected to have a higher remittance propensity compared to those who leave the country for more than a year. Finally, as described above, the descriptive data show considerable differences in the ratio of senders among all emigrants between short- and long-term migrants, as well as between current and returned emigrants.

\subsection{Regression analysis}

For the probit model, we applied the following equation to calculate change in the probability of sending remittances if the independent variable increases by one unit: ${ }^{7}$

$$
P\left(y=1 \mid x_{1}=c_{1}+1, x_{2}=c_{2}, \ldots x_{n}=c_{n}\right)-P\left(y=1 \mid x_{1}=c_{1}, x_{2}=c_{2}, \ldots x_{n}=c_{n}\right)
$$

7 Interpretation of the values in Table 3 should take into account the fact that dummy variables are constructed for the different categories in the case of categorical variables. For instance, in the case of "gender" variable, the values show the remittance propensity for females compared to all other values i.e. males. In the case of "Job", the values for agriculture and industry (ISCO 6-9) show the remittance propensity for persons working in this field compared to all other persons (i.e. working in other fields or not working at all). 
where:

- $P$ is the predicted probability of $y=1$

- $\mathrm{x}$ is the independent variables

- $\mathrm{c}$ is the constants

$\mathrm{Y}$ is the dependent variable measuring the remittance propensity of emigrants, i.e. whether the emigrant sends private transfers or not (value 1 or 0 ). We used the following independent variables ${ }^{8}$ (Table 3.)

- gender: since most Hungarian emigrants who leave the country for financial reasons are industrial workers, we expect men to have a higher remittance propensity.

- age as continuous variable: on the basis of the findings of Cai (2003), Holst/ Schrooten (2006), Ambrosetti et al. (2014) we expect older migrants to be more likely to send private transfers. This is in line with our Hungarian descriptive data, which show that blue-collar temporary workers are older than the average Hungarian emigrant.

- highest level of education: as the study of Bollard et al. (2009) showed, the relationship between education and remittance propensity diverges in different countries. In the case of Hungary, descriptive data shows that it is mainly migrants with vocational school education who are more likely to send remittances. This corresponds to the findings of Busetta et al. (2016).

- occupation abroad: descriptive data show that the short-term emigrants in Germany and Austria work mainly in blue-collar positions, accordingly we expect that those occupied in agriculture or industry are more likely to send financial support.

- purpose of emigration: higher remittance propensity is expected in the case of those who leave Hungary to work abroad.

- frequency of visiting Hungary: we expect that the more often emigrants visit their relatives in Hungary, the higher the probability of their sending remittances. This is due to the fact that, on the basis of descriptive data, short-term workers in Germany and Austria mainly leave their home on a temporary basis because of the higher income abroad.

- whether the respondent lived abroad with their parents, children or partner: since the main impetus for sending private transfers is to support family members, we expect that those who left the country with their relatives are less likely to send money to Hungary. However, it should be mentioned that, on the basis of this variable, the possibility cannot be excluded that if a migrant leaves Hungary with a family member, other relatives will remain in the country.

8 Survey questions: How often did you visit Hungary in the last 12 months of the period that you spent abroad? (Several times a month / once a month / once every 2-3 months / 1-2 times / did not visit Hungary at all in this period). What activity/ies did you do abroad? (Work / study, internship / language course / volunteering / other). What level of education did you receive while abroad? (Primary / secondary / tertiary). While you were abroad, who were you living together with? (Alone / spouse; cohabiting partner; partner / son(s); daughter(s) / parent(s) / flatmate; colleague; other). The occupations are categorised according to the International Standard Classification of Occupations (ISCO). 
- country of residence: as described above, workers who move to Germany and Austria do so mainly for financial motivations, therefore we expect a higher remittance propensity in the case of these countries.

No information was available from the Microcensus data on the sum of remittances, the income of the sender person or the receiving household.

The result of the probit regressions showed that age was the most powerful predictor in the models (second most powerful in model " $D$ ") i.e. there is a growing likelihood of remitting with increasing age (in accordance with Ambrosetti et al. 2014 and Pinger 2010). Men, especially short-term migrants, are more likely to send personal transfers, although the difference was not significant among those permanently living abroad at the time of the survey (subgroup " $\left.D^{\prime \prime}\right)$. Those who were living abroad with their parents or children were less likely to remit in all models.

Regarding educational levels, all models showed that vocational school attainment has the strongest positive effect on the sending of remittances, while models for the different emigrant subgroups indicate that people with higher educational levels are less likely to send transfers (in line with the findings of Busetta et al. 2016; Roberts et al. 2008). Model "B", however, differs from the other models, as short-term return migrants who have completed tertiary education are more likely to remit than migrants with lower levels of education. This difference might be an indicator of the changing emigration strategies in recent years and the differences between the sub-groups described above (e.g. return migrants tended to leave for different target countries, the ratio of persons born in the neighbouring countries is higher). The lower likelihood of sending remittances is especially important among current short-term emigrants (model $\mathrm{C}$ ) with a tertiary education: this is attributable to the lower number of persons in this subgroup with a university or college degree, while a higher level of education is more typical among permanent emigrants. However, as Bollard et al. (2009) concluded in their comprehensive study, it is hard to find an unequivocal connection between the level of education and remittances. With regard to primary and secondary school attainment, the results are ambiguous, and their effect was not significant.

In spite of the controlled effect of the education in the models, people working in agriculture and industry are significantly more likely to support their household members who remain behind, while people who are not working are less likely to send transfers (except from model " $\mathrm{C}$ " where this predictor was not significant). This is particularly noticeable among the short-term return migrants, as people working in agriculture and industry are even more likely to remit compared to longterm emigrants or return migrants. This is in line with our second Hypothesis of a greater remittance propensity among blue-collar workers.

Most of the models confirmed the expectations of a positive relationship between the frequency of visiting Hungary and the likelihood of remitting. Among those who visit Hungary at least once per month, the probability of sending private transfers is higher, whereas the remittance propensity of those who return to Hungary less frequently tends to decrease in line with the length of the periods, which indicates the importance of the personal relationship between the sender and the receiver. Concerning the effect of the migrants' country of residence in models " $D$ " 
Tab. 3: $\quad$ Results of probit regressions on remittance propensity (Dependent variable: the household receives remittance) (Change in the probability of sending remittances if the independent variable increases by one unit)

\begin{tabular}{|c|c|c|c|c|c|}
\hline \multirow{3}{*}{$\begin{array}{l}\text { Model } \\
\text { Type of migration }\end{array}$} & A & D & B & C & \multirow{3}{*}{ Total } \\
\hline & \multicolumn{2}{|c|}{ Long-term } & \multicolumn{2}{|c|}{ Short-term } & \\
\hline & $\begin{array}{l}\text { Return } \\
\text { migrants }\end{array}$ & Emigrants & $\begin{array}{l}\text { Return } \\
\text { migrants }\end{array}$ & Emigrants & \\
\hline Gender (female) & $-0.048^{* *}$ & NS & $-0.108^{* *}$ & $-0.156^{* *}$ & $-0.052^{* *}$ \\
\hline Age & $0.008^{* *}$ & $0.004 * *$ & $0.006^{* *}$ & $0.015^{* *}$ & $0.008^{* *}$ \\
\hline \multicolumn{6}{|l|}{ Job } \\
\hline professionals (ISCO 1-4) & NS & NS & NS & NS & NS \\
\hline services (ISCO 5) & NS & NS & NS & NS & NS \\
\hline agriculture, industry (ISCO 6-9) & $0.066^{* *}$ & $0.047^{* *}$ & $0.105^{* *}$ & NS & $0.083^{* *}$ \\
\hline not working (eg. studying) & $-0.093^{* *}$ & NS & $-0.160 * *$ & NS & $-0.074 * *$ \\
\hline \multicolumn{6}{|l|}{ Educational level } \\
\hline primary school & NS & $0.074^{* *}$ & NS & NS & $0.152^{* *}$ \\
\hline vocational school & $0.050 * *$ & $0.082 * *$ & $0.093^{* *}$ & NS & $0.202^{* *}$ \\
\hline secondary school & NS & NS & NS & $-0.114^{* *}$ & $0.093^{* *}$ \\
\hline tertiary school & $-0.047^{* *}$ & $-0.043^{* *}$ & $0.096 * *$ & $-0.379 * *$ & NS \\
\hline \multicolumn{6}{|c|}{ Activity abroad/purpose of migration } \\
\hline work & NS & $0.070^{* *}$ & NS & $0.333^{* *}$ & NS \\
\hline education & $-0.092^{* *}$ & $-0.110^{* *}$ & $-0.258^{* *}$ & NS & $-0.182^{* *}$ \\
\hline other & NS & NS & $-0.158^{* *}$ & NS & $-0.143^{* *}$ \\
\hline \multicolumn{6}{|l|}{ Frequency of visiting home } \\
\hline several times in a month & NS & $0.256^{* *}$ & NS & NS & $0.199 * *$ \\
\hline monthly & NS & $0.135 * *$ & NS & NS & $0.139 * *$ \\
\hline 2-3 monthly & $-0.053^{* *}$ & $0.079 * *$ & NS & NS & $0.085^{* *}$ \\
\hline $1-2$ annually & $-0.088^{* *}$ & NS & $-0.127 * *$ & $-0.165^{* *}$ & NS \\
\hline $\begin{array}{l}\text { did not visit Hungary at all in } \\
\text { this period }\end{array}$ & $-0.140 * *$ & NS & $-0.246^{* *}$ & $-0.220^{* *}$ & $-0.072 * *$ \\
\hline \multicolumn{6}{|l|}{ Family (parents/children) } \\
\hline abroad & $-0.114 * *$ & $-0.103^{* *}$ & $-0.114 * *$ & $-0.176^{* *}$ & $-0.091 * *$ \\
\hline \multicolumn{6}{|l|}{ Migrant's host country } \\
\hline USA & $0.086^{* *}$ & NS & NS & $-0.560 * *$ & NS \\
\hline Australia & NS & NS & $0.204^{* *}$ & NS & NS \\
\hline Austria & NS & NS & NS & NS & NS \\
\hline United Kingdom & NS & NS & $-0.056^{* *}$ & NS & NS \\
\hline Netherlands & NS & NS & NS & NS & NS \\
\hline Ireland & NS & NS & NS & NS & NS \\
\hline Germany & NS & NS & NS & NS & NS \\
\hline Switzerland & NS & NS & NS & NS & NS \\
\hline Sweden & NS & NS & NS & NS & NS \\
\hline other country & NS & NS & NS & NS & NS \\
\hline Time spent abroad (years) & - & $0.006^{* *}$ & - & - & - \\
\hline $\mathrm{N}$ & 11114 & 3192 & 8755 & 1173 & 12749 \\
\hline $\mathrm{R}^{2}$ (Nagelkerke) & 0.436 & 0.375 & 0.441 & 0.509 & 0.375 \\
\hline
\end{tabular}

**** indicates significance at 5 percent and 1 percent level respectively.

Source: Authors' calculations based on Microcensus 2016 survey 
and "Total", none of them proved to be significant. In model " $\mathrm{A}$ " and " $\mathrm{C}$ " the results showed that residency in the USA had a positive effect, while in model " $\mathrm{B}$ ", living in Australia had a positive effect and residing in the U.K. had a negative effect on sending remittances. These results therefore do not support our initial expectation that those who leave Hungary for Austria and Germany would have a higher remittance propensity.

After analysing the determining factors of remittance propensity (i.e. whether a migrant sends money or not) on the basis of Microcensus data, in the second stage we used linear regressions of the "Family transfers" dataset to identify the key variables which determine the sum of the transfer (Table 4). Our objective at this stage was to reveal the characteristics of remittance-sender emigrants which influence how much they send. We also intended to find the differences in the determining factors between short- and long-term emigrants, in order to ascertain whether there are any effects which are peculiar to only one group.

Besides the total dataset, we created two subsets based on the senders' length of stay abroad. One subset for long-term migrant senders, i.e. those remittance senders who stayed or intended to stay abroad for at least one year, and one for short-term migrant senders. We used the inverse Mills ratios composed from the Microcensus subgroups " $A$ " and " $D$ " in the linear regressions of the "Long-term" subset and the inverse Mills ratios of subgroups " $B$ " and " $C$ " for the regressions in the "Short-term" subset in order to mitigate selection bias. Data on the income of the sender were available in approximately half of the cases, thus we calculated regressions by: 1 . using senders' income data, 2 . omitting them, or 3 . substituting the missing income data with mean income. Since the results showed that the sender's income is one of the key explanatory variables, and the second and third options provided less effective models, we present the results of the models containing the logarithm of the sender's income as an independent variable. We estimated the following equation by ordinary least squares (OLS):

$$
\log (\text { remit })=\beta_{0}+\beta_{1} \text { migrchar }+\beta_{2} \text { country }+\beta_{3} \log (\text { hhinc })+\beta_{4} \log (\text { sendinc })+\beta_{5} \text { mills }+\mu
$$

where:

- $\log$ (remit) is the logarithm of remittances sent in 2016

- migrchar is the sociodemographic variables of the sender such as

- gender: since the ratio of male senders is almost 62 percent and they are more likely to leave Hungary for financial reasons, we expect that men will tend to send a higher sum of remittances.

- age-squared: approximately two-thirds of senders are between 25 and 44 years of age. Age is squared to control for nonlinearities. We expect to see a positive relationship with the sum of remittances.

- occupation: three main categories were constructed, white-collar workers (ISCO groups 1-4), employees in the service sector (ISCO group 5) and blue-collar workers (ISCO groups 6-9). On the basis of descriptive data and probit regressions, we expect blue-collar workers to send more money. 
- educational level: more than half of the senders have vocational or secondary school level education, but among long-term migrants, the ratio of persons with vocational school is lower, while the ratio of senders with a college or university degree is higher. We expect a higher level of education to be associated with a lower sum of remittances, since, in the case of Hungary, the group of temporary workers with a vocational school education dominate remittance flows.

- frequency of visits home: the variable is used as a dummy to capture the strength of relationship between the sender and the receiver. Personal visits also make it possible to bring home money in cash instead of the more expensive electronic methods. We expect that those who visit home more frequently will tend to send more money, in line with Holst/Schrooten (2006).

- family members abroad: the value of the variable is 0 if children, parents, spouse/partner also moved abroad and 1 if the sender migrated alone or with friends or colleagues. We expect that those who leave Hungary with their relatives will tend to send less money. However, it should be mentioned that, on the basis of this variable, the possibility cannot be excluded of other relatives remaining in the country if a migrant leaves Hungary with a family member.

- country is the emigrants' host country: On the basis of descriptive data, persons residing in Austria or Germany are expected to remit more than those living in the UK.

- $\log ($ hhinc) is the logarithm of the monthly per capita income of the remittance receiver household in Hungary. We expect a negative relationship between the sum of remittances and the receiver household's income level.

- $\log ($ sendinc) is the logarithm of the monthly income of the remittance sender. Based on the literature, there is likely to be a positive association with the amount of private transfers.

- Mills is the selection bias calculated from Microcensus probit regressions

The results of partial variable effect estimations showed in all models that those with a higher income tend to send more money to the household members left behind (in line with the findings of e.g. Unheim/Rowlands 2012; Cai 2003), while a negative relationship was ascertained regarding the income of the receiving household. In other words, if the migrants' income is higher or the receiving household's income is lower, migrants tend to send a higher sum of remittances regardless of whether they reside abroad permanently or temporarily. Within the theoretical framework of NELM, this supports our first Hypothesis on the altruistic motives of sending remittance rather than the exchange-type attitudes described by Cox et al. (1998). The separate handling meant that the changes in remittance sending habits and motivations over time in short- and long-term migrants described by Cox et al. (2004) or Simkova/Langhamrova (2015), for instance, were not borne out.

Concerning other variables, the determinants of the amount of remittance and the probability of remitting are similar in several aspects. The gender variable was significant only in the case of short-term models and when all migrants were considered (i.e. Total model), and results showed that women are not only less likely to remit but also tend to send lower amounts (in accordance with e.g. Amuedo- 
Tab. 4: OLS coefficients predicting the annual log amount remitted to Hungary

\begin{tabular}{|c|c|c|c|c|c|}
\hline \multirow{3}{*}{$\begin{array}{l}\text { Model } \\
\text { Type of migration }\end{array}$} & A & D & B & C & \\
\hline & \multicolumn{2}{|c|}{ Long-term } & \multicolumn{2}{|c|}{ Short-term } & \multirow[t]{2}{*}{ Total } \\
\hline & $\begin{array}{l}\text { Return } \\
\text { migrants }\end{array}$ & Emigrants & $\begin{array}{l}\text { Return } \\
\text { migrants }\end{array}$ & Emigrants & \\
\hline \multirow[t]{2}{*}{ Gender $($ male $=0)$} & -0.422 & -0.196 & $-0.477^{*}$ & $-0.488^{*}$ & $-0.518 * *$ \\
\hline & $(-1.75)$ & $(-0.86)$ & $(-2.11)$ & $(-2.11)$ & $(-3.00)$ \\
\hline \multirow[t]{2}{*}{ Age-squared } & -0.001 & 0.001 & omitted & omitted & omitted \\
\hline & $(-1.19)$ & $(1.13)$ & & & \\
\hline \multicolumn{6}{|c|}{ Job (professionals (ISCO 1-4) $=0$ ) } \\
\hline \multirow{2}{*}{ services (ISCO 5) } & -0.118 & -0.155 & 0.559 & 0.447 & 0.239 \\
\hline & $(-0.37)$ & $(-0.50)$ & $(1.76)$ & $(1.35)$ & $(1.01)$ \\
\hline \multirow[t]{2}{*}{ agriculture, industry (ISCO 6-9) } & 0.417 & 0.533 & $0.662^{*}$ & 0.057 & $0.525^{*}$ \\
\hline & $(1.39)$ & (1.59) & $(1.98)$ & $(0.19)$ & $(2.26)$ \\
\hline \multicolumn{6}{|c|}{ Educational level (BA degree or higher $=0$ ) } \\
\hline \multirow[t]{2}{*}{ primary school } & -0.920 & -0.893 & $1.349 * *$ & $1.426 * *$ & 0.362 \\
\hline & $(-1.61)$ & $(-1.39)$ & $(3.29)$ & $(3.36)$ & $(0.94)$ \\
\hline \multirow[t]{2}{*}{ vocational school } & 0.599 & 0.186 & $1.398 * *$ & $0.867 * *$ & $0.711 * *$ \\
\hline & $(1.89)$ & $(0.53)$ & $(4.17)$ & $(2.70)$ & $(3.22)$ \\
\hline \multirow[t]{2}{*}{ secondary school } & $0.662^{*}$ & 0.365 & $0.772^{*}$ & 0.597 & $0.445^{*}$ \\
\hline & $(2.36)$ & $(1.28)$ & $(2.34)$ & $(1.79)$ & $(2.04)$ \\
\hline \multicolumn{6}{|c|}{ Frequency of visiting home ( 0 times $=0$ ) } \\
\hline \multirow{2}{*}{ several times in a month } & 1.427 & 1.066 & $2.600 * *$ & $1.775 * *$ & $1.632 * *$ \\
\hline & $(1.86)$ & $(1.30)$ & $(4.76)$ & $(3.48)$ & $(3.32)$ \\
\hline \multirow[t]{2}{*}{ monthly } & $2.057 * *$ & $1.549 * *$ & $1.689 * *$ & 0.864 & 0.659 \\
\hline & $(3.47)$ & $(2.68)$ & $(2.89)$ & $(1.52)$ & $(1.44)$ \\
\hline \multirow[t]{2}{*}{ 2-3 monthly } & 0.366 & 0.451 & $1.740 * *$ & $0.889 *$ & 0.510 \\
\hline & $(0.75)$ & $(0.91)$ & (3.29) & (2.10) & (1.39) \\
\hline \multirow[t]{2}{*}{ 1-2 annually } & 0.007 & 0.039 & 0.938 & 0.088 & -0.091 \\
\hline & $(0.01)$ & $(0.08)$ & $(1.87)$ & $(0.22)$ & $(-0.25)$ \\
\hline \multicolumn{6}{|l|}{ Family abroad (children, } \\
\hline parents, spouse/partner & -0.059 & 0.252 & -0.243 & 0.126 & 0.032 \\
\hline abroad $=0$ ) & $(-0.28)$ & $(1.22)$ & $(-1.21)$ & $(0.73)$ & $(0.24)$ \\
\hline \multicolumn{6}{|l|}{ Migrant's host country $(U K=0)$} \\
\hline \multirow[t]{2}{*}{ country_US } & 1.272 & 0.976 & & & \\
\hline & $(1.92)$ & $(1.50)$ & & & \\
\hline \multirow[t]{2}{*}{ country_AT } & -0.035 & 0.043 & 0.177 & 0.183 & 0.218 \\
\hline & $(-0.09)$ & $(0.11)$ & $(0.53)$ & $(0.54)$ & $(0.85)$ \\
\hline \multirow[t]{2}{*}{ country_NL } & $-1.543 * *$ & $-1.587 * *$ & -0.526 & -0.544 & $-0.928 *$ \\
\hline & $(-4.20)$ & $(-4.37)$ & $(-0.60)$ & $(-0.67)$ & $(-1.96)$ \\
\hline country_IE & -0.007 & 0.146 & & & \\
\hline & $(-0.01)$ & $(0.27)$ & & & \\
\hline country_DE & 0.153 & 0.162 & 0.188 & 0.241 & 0.180 \\
\hline & $(0.48)$ & $(0.50)$ & $(0.62)$ & $(0.78)$ & $(0.81)$ \\
\hline country_CH & $1.543 * *$ & $1.171 * *$ & -0.047 & -0.625 & 0.482 \\
\hline & $(3.59)$ & $(2.67)$ & $(-0.14)$ & $(-1.72)$ & $(1.03)$ \\
\hline country_OTHER ${ }^{1}$ & 0.538 & 0.543 & 0.550 & 0.077 & -0.266 \\
\hline & $(1.49)$ & $(1.50)$ & $(0.18)$ & $(0.24)$ & $(-1.06)$ \\
\hline
\end{tabular}


Tab. 4: Continuation

\begin{tabular}{|c|c|c|c|c|c|}
\hline \multirow{3}{*}{$\begin{array}{l}\text { Model } \\
\text { Type of migration }\end{array}$} & A & D & $B$ & C & \multirow{3}{*}{ Total } \\
\hline & \multicolumn{2}{|c|}{ Long-term } & \multicolumn{2}{|c|}{ Short-term } & \\
\hline & $\begin{array}{l}\text { Return } \\
\text { migrants }\end{array}$ & Emigrants & $\begin{array}{l}\text { Return } \\
\text { migrants }\end{array}$ & Emigrants & \\
\hline \multirow{3}{*}{$\begin{array}{l}\text { Receiving household income } \\
\text { (log) } \\
\text { Migrant's income (log) }\end{array}$} & $-0.619 * *$ & $-0.582 * *$ & $-0.455^{* *}$ & $-0.464 * *$ & $-0.533 * *$ \\
\hline & $(-3.18)$ & $(-2.97)$ & $(-2.86)$ & $(-2.98)$ & $(-4.42)$ \\
\hline & $\begin{array}{l}0.433^{* *} \\
(3.27)\end{array}$ & $\begin{array}{l}0.462^{* *} \\
(3.52)\end{array}$ & $\begin{array}{l}0.185^{*} \\
(2.12)\end{array}$ & $\begin{array}{l}\mathbf{0 . 1 7 8}^{*} \\
(2.05)\end{array}$ & $\begin{array}{l}0.359^{* *} \\
(4.71)\end{array}$ \\
\hline \multirow[t]{2}{*}{ Mills } & $-7.425^{* *}$ & -0.617 & $-6.886 * *$ & $-1.163^{* *}$ & $-4.150 * *$ \\
\hline & $(-2.71)$ & $(-0.13)$ & $(-4.46)$ & $(-4.14)$ & $(-5.38)$ \\
\hline _cons & $\begin{array}{c}13.535^{* *} \\
(4.06)\end{array}$ & $\begin{array}{c}10.100 * * \\
(3.00)\end{array}$ & $\begin{array}{c}15.746^{* *} \\
(6.44)\end{array}$ & $\begin{array}{c}16.486 * * \\
(6.52)\end{array}$ & $\begin{array}{c}13.600 * * \\
(733)\end{array}$ \\
\hline $\mathrm{N}$ & 325 & 325 & 330 & 330 & 655 \\
\hline $\mathrm{R}^{2}$ & 0.362 & 0.346 & 0.388 & 0.388 & 0.331 \\
\hline
\end{tabular}

1 Other countries: in the case of total and short-term models, other countries include Australia, Belgium, Canada, France, Ireland, Italy, Norway, Spain, Sweden, the USA and those senders who did not respond to this question. In the case of long-term models, there were enough records to cover senders from Ireland and the US in separate categories as well.

Numbers in parenthesis are t-statistics. ${ }^{*},{ }^{* *}$ indicates significance at 5 percent and 1 percent level respectively.

Source: Authors' calculations based on Family transfers survey 2017

Dorantes/Pozo 2006). The age distribution of senders was not linear, accordingly we tried to capture the effects both with age categories and by using an age-squared variable. In the case of short-term and total models, the age variable had to be omitted due to multicollinearity, while in the long-term models the association was not significant.

Since the number of emigrants who make private transfers to Hungary but did not have a job was negligible, we omitted these cases from our models. Among long-term emigrants the occupation variable was not significant, whereas among the temporary workers abroad, those who work in agriculture and different fields of industry tend to send larger remittances compared to those who are in white-collar positions. These findings correspond to the results in Macedonia (Roberts et al. 2008). From the perspective of the educational level of emigrants, our results were similar to those of probit regressions, supporting our second Hypothesis. In the case of short-term emigrants, primary or vocational school level education is associated with significantly higher money flows to the household members left behind compared to those with tertiary education. This finding is not in line with the results of Busetta et al. (2016) or Pinger (2010). However, as Bollard et al. (2009) described, the relationship between remittances and educational level can vary among countries. In the case of Hungary, a large number of blue-collar workers left the country without any further goals (like making a career or starting a new life abroad), but in- 
tended to make private transfers during their residence abroad, which might explain why lower-level education is associated with higher transfer sums.

The variable concerning the frequency of visits home also proved to be significant, in line with the results of probit regressions on remittance propensity. When permanent emigrants pay monthly visits to Hungary, the level of the money flow is significantly higher compared to those who never travel back. As far as short-term emigrants are concerned, the sum of private transfers from those who come back to Hungary several times per month or every $2-3$ months was also significantly higher. This also possibly highlights the strategy of those migrants who leave Hungary only on account of the higher income in short-term industry jobs, but who do not plan to reside abroad for a longer period.

Concerning the migrants' country of residence, no significant difference was identified between the three main target countries for Hungarians (i.e. Austria, Germany and the UK). The geographical region of employment was important only with regard to permanent emigrants. Within this group, those who reside in the Netherlands send significantly less, while those in Switzerland significantly more compared to Hungarians who reside in the United Kingdom.

In four of the five models, selection bias (inverse Mills ratios) was also significant, which draws attention to the way in which this issue is handled e.g. with our two-step approach to the surveys.

Since the Family transfers survey also contained questions regarding the time of emigration and the intended date of return, we ran OLS models including these variables for long-term emigrants (Table 5). Concerning short-term migrants, the estimations using these two additional variables are clearly superfluous, since these persons leave Hungary for less than a year. Therefore, we omitted this sender population, and used the data only for those who have a permanent residence abroad, i.e. they live in a foreign country permanently. In order to test the significance of their intention to return home, we used a dummy variable on whether these emigrants have any plans to move back to Hungary or not. The value of the variable is " 0 " if the sender plans to move back to Hungary and " 1 " if the sender has no such intention. The results revealed a negative relationship between the sum of money transfers and the intention of returning home. This means that those with no plan to reside abroad permanently tend to send higher amounts than emigrants who envisage their future in a foreign country in the long run, while the intention to stay in another country is associated with lower money flows. This provides further information on migrants' primary motivations when sending remittances: our results generally confirm mainly altruistic attitudes in Hungarian emigrants, however this latter outcome also implies self-interest behind these money flows. Those emigrants who plan to return to Hungary tend to send higher amounts, presumably to secure a stronger position, both financially and socially, within their families. Emigrants who have no intention of returning send lower amounts by contrast, since their main priority is establishing a new life abroad rather than supporting their relatives who remained behind. 
Tab. 5: Results of regressions for long-term emigrants in Family transfers survey (dependent variable: Annual log amount remitted to Hungary)

\begin{tabular}{|c|c|c|}
\hline \multirow{3}{*}{$\begin{array}{l}\text { Model } \\
\text { Type of migration }\end{array}$} & A & D \\
\hline & \multicolumn{2}{|c|}{ Long-term } \\
\hline & $\begin{array}{l}\text { Return } \\
\text { migrants }\end{array}$ & Emigrants \\
\hline Gender $($ male $=0)$ & $\begin{array}{l}-0.324 \\
(-1.35)\end{array}$ & $\begin{array}{l}-0.139 \\
(-0.62)\end{array}$ \\
\hline Age-squared & $\begin{array}{l}-0.001 \\
(-0.80)\end{array}$ & omitted \\
\hline Time abroad & $\begin{array}{l}-0.019 \\
(-1.01)\end{array}$ & $\begin{array}{l}-0.500 \\
(-1.83)\end{array}$ \\
\hline Intention of returning home (any plans to return home $=0$ ) & $\begin{array}{l}-0.754 * * \\
(-2.60)\end{array}$ & $\begin{array}{l}-0.727^{*} \\
(-2.47)\end{array}$ \\
\hline \multicolumn{3}{|l|}{ Job (professionals (ISCO 1-4) =0) } \\
\hline services (ISCO 5) & $\begin{array}{l}-0.167 \\
(-0.53)\end{array}$ & $\begin{array}{l}-0.166 \\
(-0.53)\end{array}$ \\
\hline agriculture, industry (ISCO 6-9) & $\begin{array}{l}0.431 \\
(1.47)\end{array}$ & $\begin{array}{l}\text { 0.758* } \\
(2.32)\end{array}$ \\
\hline no job & omitted & omitted \\
\hline \multicolumn{3}{|l|}{ Educational level (BA degree or higher $=0$ ) } \\
\hline primary school & $\begin{array}{l}-0.789 \\
(-1.35)\end{array}$ & $\begin{array}{l}-0.330 \\
(-0.52)\end{array}$ \\
\hline vocational school & $\begin{array}{l}0.558 \\
(1.69)\end{array}$ & $\begin{array}{l}\text { 0.639* } \\
(1.99)\end{array}$ \\
\hline secondary school & $\begin{array}{l}0.559 \\
(1.90)\end{array}$ & $\begin{array}{l}0.506 \\
(1.84)\end{array}$ \\
\hline \multicolumn{3}{|l|}{ Frequency of visiting home ( 0 times $=0$ ) } \\
\hline several times in a month & $\begin{array}{l}1.264 \\
(1.64)\end{array}$ & $\begin{array}{l}1.618^{*} \\
(2.01)\end{array}$ \\
\hline monthly & $\begin{array}{l}1.847 * * \\
(3.15)\end{array}$ & $\begin{array}{l}1.313^{*} \\
(2.38)\end{array}$ \\
\hline 2-3 monthly & $\begin{array}{l}0.319 \\
(0.69)\end{array}$ & $\begin{array}{l}0.356 \\
(0.78)\end{array}$ \\
\hline 1-2 annually & $\begin{array}{l}0.028 \\
(0.06)\end{array}$ & $\begin{array}{l}0.053 \\
(0.12)\end{array}$ \\
\hline Family abroad (children, parents, spouse/partner abroad $=0$ ) & $\begin{array}{l}-0.137 \\
(-0.65)\end{array}$ & $\begin{array}{l}-0.089 \\
(-0.42)\end{array}$ \\
\hline
\end{tabular}


Tab. 5: Continuation

\begin{tabular}{|c|c|c|}
\hline \multirow{3}{*}{$\begin{array}{l}\text { Model } \\
\text { Type of migration }\end{array}$} & A & D \\
\hline & \multicolumn{2}{|c|}{ Long-term } \\
\hline & $\begin{array}{l}\text { Return } \\
\text { migrants }\end{array}$ & Emigrants \\
\hline \multicolumn{3}{|l|}{ Migrant's host country (UK $=0$ ) } \\
\hline \multirow[t]{2}{*}{ country_US } & $1.358^{*}$ & 1.071 \\
\hline & $(2.23)$ & $(1.95)$ \\
\hline \multirow[t]{2}{*}{ country_AT } & -0.019 & 0.011 \\
\hline & $(-0.05)$ & $(0.03)$ \\
\hline \multirow[t]{2}{*}{ country_NL } & $-1.564 * *$ & $-1.511 * *$ \\
\hline & $(-3.74)$ & $(-3.81)$ \\
\hline \multirow[t]{2}{*}{ country_IE } & 0.184 & 0.240 \\
\hline & $(0.34)$ & $(0.44)$ \\
\hline \multirow[t]{2}{*}{ country_DE } & 0.180 & 0.200 \\
\hline & $(0.58)$ & $(0.65)$ \\
\hline \multirow[t]{2}{*}{ country_CH } & $1.289 * *$ & $1.009 * *$ \\
\hline & $(3.18)$ & $(2.59)$ \\
\hline \multirow[t]{2}{*}{ country_OTHER } & 0.627 & 0.645 \\
\hline & $(1.68)$ & $(1.72)$ \\
\hline \multirow[t]{2}{*}{ Receiving household income (log) } & $-0.558 * *$ & $-0.556 * *$ \\
\hline & $(-2.94)$ & $(-2.95)$ \\
\hline \multirow[t]{2}{*}{ Migrant's income (log) } & $0.496 * *$ & $0.512 * *$ \\
\hline & $(3.76)$ & $(3.88)$ \\
\hline \multirow[t]{2}{*}{ Mills } & $-6.985^{*}$ & $-3.704 *$ \\
\hline & $(-2.40)$ & $(-2.42)$ \\
\hline \multirow[t]{2}{*}{ _cons } & $12.548 * *$ & $11.924 * *$ \\
\hline & $(3.82)$ & (3.89) \\
\hline $\mathrm{N}$ & 325 & 325 \\
\hline $\mathrm{R}^{2}$ & 0.387 & 0.378 \\
\hline
\end{tabular}

Numbers in parenthesis are t-statistics. ${ }^{*},{ }^{*}$ indicates significance at 5 percent and 1 percent level respectively.

Source: Authors' calculations based on Family transfers survey

\section{Conclusions}

The study aimed to gain a better understanding of the socio-economic drivers of emigration and remittances in the case of Hungary, using the results of the Microcensus large-sample survey and the first remittance-specific household survey in the country. So far, the effect on host countries' labour-markets has been the main emphasis concerning intra-EU migrants from the eastern member states instead of other aspects of these population movements, such as private money transfers. Analyses were mainly based on macro-level data, which offered no possibility for a more profound examination of the socio-economic characteristics of sender per- 
sons and receiving households. The results provide a contribution to further research on the drivers of labour migration and the differences between short- and long-term emigrants.

The results of the probit regressions indicate that Hungarian emigrants have a higher remittance propensity if their highest level of education is vocational school, or if they work abroad in agriculture or industry. With increasing age and frequency of visits home, there is a growing likelihood of their making private transfers, and males are more likely to support their relatives who remain in Hungary. Using the theoretical framework of NELM, our results provide evidence for the altruistic motivations of emigrants, since a strong positive relationship could be identified with the senders' income in accordance with the findings of Unheim/Rowlands (2012) and Cai (2003). With regard to the receiving households' income, however, the direction of the relationship is quite the opposite. As Cox et al. (2004) showed, these motivations can change with the time spent abroad. Accordingly, our examinations also distinguished between permanent and temporary workers abroad. Our crosssectional data do not make it possible to capture any changes in sending habits over time, nevertheless we found that the relationship with income variables holds both in the case of short- and long-term migrants. It was also confirmed that permanent emigrants who have no intention of returning home tend to send significantly less money. On the one hand this implies self-interest as a motivation alongside altruism, on the other hand it reveals differences in the amounts of remittance sent based on the length of time spent abroad.

According to our results, those who left the country with their family have a lower remittance propensity, while the variable was not significant concerning the amount of money sent. A possible explanation of this latter result is that our variable did not cover the case of an entire family leaving the country, but referred only to those cases in which a relative (spouse, child, parent) accompanied the migrant abroad. In other words, on the basis of the data in the two datasets, it cannot be excluded that other relatives stayed in Hungary, even if a family member accompanied the sender migrant abroad.

The results showed that those who have a vocational school education and work in blue-collar jobs are the most affected. From a public policy perspective this can be important, since it is in line with the research of Hárs and Simon $(2016,2017)$, who found that emigration has the largest effect on the Hungarian labour-market (i.e. shortage of workers) in these areas. This showed that it is possible to influence labour-market issues by reducing the volume of emigration - and thus the loss of young and qualified human capital. This can be achieved in various ways, e.g. increased state support for training courses in the blue-collar jobs affected, or by launching programmes in which the state covers the costs of the vocational training but the contracts include a mandatory number of working years in Hungary. Reduced tax and social security burdens for employees in these occupations are also conceivable. This also marks a possible direction for future research, i.e. analysing remittances from the receiving household side as well by identifying the most important determining factors of receiving remittances beyond income, e.g. housing circumstances or deprivation factors. 
The above methodology can also serve as a practical model for other countries in the region. It highlights the importance of censuses or microcensuses when examining international migration. In several countries, the lack of appropriately accurate data on the registration and deregistration of population movements means that administrative datasets provide little or no reliable insight into migration and remittance flows, making utilisation of these large-sample surveys essential. They can be the starting point for further specific field work in which more sensitive topics - for instance financial matters and money flows - can be analysed. This twostep approach also supports the handling of selection bias in order to draw accurate conclusions.

\section{References}

Acosta, Pablo et al. 2008: What is the impact of international remittances on poverty and inequality in Latin-America? In: World Development 36,1: 88-114 [doi: 10.1016/j. worlddev.2007.02.016].

Akkoyunlu, Aule; Kholodilin, Konstantin 2008: A link between workers' remittances and business cycles in Germany and Turkey. In: Emerging Markets Finance and Trade 44,5: 23-40 [doi: 10.2753/REE1540-496X440502].

Ambrosetti, Elena et al. 2014: Ukrainian migrants in the European Union: A comparative study of the Czech Republic and Italy. In: Sociologija i prostor 52: 141-166 [doi: 10.5673/sip.52.2.2].

Amuedo-Dorantes, Catalina; Pozo, Susan 2006: Remittances as insurance: Evidence from Mexican immigrants. In: Journal of Population Economics 19,2: 227-254 [doi: 10.1007/s00148-006-0079-6].

Blaskó, Zsuzsa 2014: Surveying the Absentees - Surveying the Emigrants. SEEMIG Working Papers No. 4. Hungarian Demographic Research Institute.

Blaskó, Zsuzsa; Gödri, Irén 2014: Kivándorlás Magyarországról: Szelekció és célországválasztás az „új migránsok” körében. In: Demográfia 57,4: 271-307.

Blaskó, Zsuzsa; Gödri, Irén 2016: The social and demographic composition of emigrants from Hungary. In: Blaskó, Zsuzsa; Fazekas, Károly (Eds.): The Hungarian labour market. Institute of Economics, Centre for Economic and Regional Studies. Hungarian Academy of Sciences.

Bollard, Albert; Morten, Melanie; Rapoport, Hillel 2009: Remittances and the brain drain revisited: The microdata show that more educated migrants remit more. Working $\mathrm{Pa}$ pers 26. Bar-Ilan University: Department of Economics.

Brown, Richard P.C. et al. 2014: Measuring remittances through surveys: Methodological and conceptual issues for survey designers and data analysts. In: Demographic Research 31,41: 1243-1274 [doi: 10.4054/DemRes.2014.31.41].

Busetta, Annalisa; Cetorelli, Valeria; Stranges, Manuela 2016: Remittance behaviours of foreigners in Italy. In: International Migration 54,2: 98-118 [doi: 10.1111/imig.12213].

Cai, Qian 2003: Migrant remittances and family ties: a case study in China. In: International Journal of Population Geography 9,6: 471-483 [doi: 10.1002/ijpg.305].

Cox, Donald; Eser, Zekeriya; Jimenez, Emmanuel 1998: Motives for private transfers over the life cycle: An analytical framework and evidence for Peru. In: Journal of Development Economics 55: 57-80 [doi: 10.1016/S0304-3878(97)00056-4]. 
Cox, Donald; Hansen, Bruce; Jimenez, Emmanuel 2004: How responsive are private transfers to income? Evidence from a laissez-faire economy. In: Journal of Public Economy 88: 2193-2219 [doi: 10.1016/S0047-2727(03)00069-0].

Csortos, Orsolya; Kóczián, Balázs 2017: An analysis of the incomes and current personal transfers of Hungarians living abroad. In: Financial and Economic Review 16,2: 5-27.

Czaika, Mathias; Spray, John 2013: Drivers and dynamics of internal and international remittances. In: The Journal of Development Studies 49,10: 1299-1315 [doi: 10.1080/00220388.2013.800861].

de Haas, Hein 2012: The migration and development pendulum. A critical view on research and policy. In: International migration 50,3: 8-25 [doi: 10.1111/j.14682435.2012.00755.x].

Dickmann, Ádám; Ligeti, Anna Sára 2018: Mikrocenzus 2016: 10. Nemzetközi vándorlás. Központi Statisztikai Hivatal, 2018.

Durand, Jorge et al. 1996: International migration and development in Mexican communities. In: Demography 33,2: 249-264 [doi: 10.2307/2061875].

Dustmann, Christian; Mestres, Josep 2010: Remittances and temporary migration. In: Journal of Development Economics 92,1: 62-70 [doi: 10.1016/j.jdeveco.2008.12.002].

Eurostat 2019: Eurostat database ‘Personal transfers and compensation of employees [http://appsso.eurostat.ec.europa.eu/nui/show.do?wai=true\&dataset=bop_rem6, 01.07.2019].

Fawcett, James; Arnold Fred 1987: The role of surveys in the study of international migration: an appraisal. In: International Migration Review 21,4: 1523-1540 [doi. 10.1177/019791838702100427].

Gibson, John; McKenzie, David 2017: How reliable are survey estimates of remittances? Evidence from a cross-reporting survey exercise. In: Migration Studies 5,1: 97-115 [doi: 10.1093/migration/mnw029].

Hárs, Ágnes 2016: Emigration and immigration in Hungary after the regime change - by international comparison. In: Blaskó, Zsuzsa; Fazekas, Károly (Eds.): The Hungarian labour market 2016. Institute of Economics, Centre for Economic and Regional Studies. Hungarian Academy of Sciences.

Hárs, Ágnes; Simon, Dávid 2016: Labour migration, cross-border commuting, emigration. In: Blaskó, Zsuzsa; Fazekas, Károly (Eds.): The Hungarian labour market 2016. Institute of Economics, Centre for Economic and Regional Studies. Hungarian Academy of Sciences.

Hárs, Ágnes; Simon, Dávid 2017: A külföldi munkavállalás és a munkaerőhiány. In: Fazekas, Károly; Köllö, János (Eds.): The Hungarian labour market 2017. Institute of Economics, Centre for Economic and Regional Studies. Hungarian Academy of Sciences.

Hathroubi, Salem; Aloui, Chaker 2016: On interactions between remittance outflows and Saudi Arabian macroeconomy: New evidence from wavelets. In: Economic Modelling 59: 32-45 [doi: 10.1016/j.econmod.2016.06.018].

Heckman, James 1976: The common structure of statistical models of truncation, sample selection and limited dependent variables and a simple estimator for such models. In: Annals of Economic and Social Measurement 5: 475-492.

Holst, Elke; Schrooten Mechthild 2006: Migration and money: What determines remittances? Evidence from Germany. DIW Discussion Papers 566.

Hungarian Central Statistical Office (HCSO) 2017 (in Hungarian): Új magyar állampolgárok. Változások az egyszerűsített honosítási eljárás bevezetése után. Központi Statisztikai Hivatal, 2017. 
International Monetary Fund (IMF) 2009: Balance of payments and international investment position manual 6th edition. International Monetary Fund. Washington D.C.

Kajdi, László 2016: Remittances to Hungary and how to measure them, In: Blaskó, Zsuzsa; Fazekas, Károly (Eds.): The Hungarian labour market. Institute of Economics, Centre for Economic and Regional Studies. Hungarian Academy of Sciences.

Kajdi, László 2018: Remittances - First results of a New Survey. In: Financial and Economic Review 17,3: 85-108.

Koc, Ismet; Onan, Isil 2006: International Migrants Remittances and Welfare Status of the Left-Behind Families in Turkey. In: International Migration Review 38,1: 78-112 [doi: 10.1111/j.1747-7379.2004.tb00189.x].

Koechlin, Valerie; Leon, Gianmarco 2007: International Remittances and Income Inequality: An Empirical Investigation. In: Journal of Economic Policy Reform 10,2: 123 141 [doi: 10.1080/17487870701346514].

Leon-Ledesma, Miguel; Piracha, Matloob 2004: International migration and the role of remittances in Eastern Europe. In: International Migration 42,4: 65-83 [doi: 10.1111/j.0020-7985.2004.00295.x].

Licuanan, Victoria; Mahmoud, Toman O.; Steinmayr, Andreas 2015: The Drivers of Diaspora Donations for Development: Evidence from the Philippines. In: World Development 65: 94-109 [doi: 10.1016/j.worlddev.2014.05.010].

Lucas, Robert; Stark, Oded 1985: Motivations to Remit: Evidence from Botswana. In: The Journal of Political Economy 93,5: 901-918.

Massey, Douglas S. 1988: Economic development and international migration in comparative perspective. In: Population and Development Review 14,3: 383-413 [doi: 10.2307/1972195].

Massey, Douglas S. 1990: Social structure, household strategies, and the cumulative causation of migration. In: Population Index 56,1: 3-26 [doi: 10.2307/3644186].

Orozco, Manue/ 2005: Diasporas, Development and Transnational integration: Ghanaians in the U.S., U.K. and Germany. Institute for the Study of International Migration and the Inter-American Dialogue. Washington, DC.

Piché, Victor 2013: Contemporary migration theories as reflected in their founding texts. In: Population-E 68,1: 141-164 [doi: 10.3917/popu.1301.0153].

Pinger, Pia 2010: Come back or stay? Spend here or there? Return and remittances: The case of Moldova. In: International Migration 48,5: 142-173 [doi: 10.1111/j.14682435.2009.00562.x].

Ratha Dilip; Mohapatra, Sanket 2010: The impact of the Global Financial Crisis on migration and remittances. In: Canuto, Otaviano; Giugale, Marcelo (Eds.): The day after tomorrow. A handbook on the future of economic policy in the developing world. The World Bank. Washington, D.C.

Roberts, Brian et al. 2008: A study on determinants and trends in remittance flows in Macedonia. In: CEA Journal of Economics 3,1: 41-61.

Sirkeci, Ibrahim; Cohen, Jeffrey H.; Ratha, Dilip (Eds.) 2012: Migration and remittances during the global financial crisis and beyond. The World Bank. Washington, D.C.

Šimková, Martina; Langhamrová, Jitka 2015: Remittances and their impact on the Czech economy. In: Prague Economic Papers 24,05: 562-580.

Stark, Oded; Bloom, David E. 1985: The new economics of labor migration. Papers and Proceedings of the Ninety-Seventh Annual Meeting of the American Economic Association (May, 1985). In: The American Economic Review 75,2: 173-178. 
Stark, Oded; Lucas Robert 1988: Migration, remittances, and the family. In: Economic Development and Cultural Change 36,3: 465-481.

Stark, Oded; Taylor, J. Edward 1989: Relative deprivation and international migration. In: Demography 26,1: 1-14 [doi: 10.2307/2061490].

Taylor, Edward J. 1999: The new economics of labour migration and the role of remittances in the migration process. In: International Migration 37,1: 63-88 [doi: 10.1111/14682435.00066].

Unheim, Per; Rowlands, Dane 2012: Micro-level determinants of remittances from recent migrants to Canada. In: International Migration 50,4: 124-139 [doi: 10.1111/j.14682435.2011.00718.x].

Vargas-Silva, Carlos 2008: Are remittances manna from heaven? A look at the business cycle properties of remittances. In: The North American Journal of Economics and Finance 19,3: 290-303.

László Kajdi $(\bowtie)$. University of Pécs, Faculty of Sciences. Pécs, Hungary.

E-mail: kajdil@mnb.hu

URL: https://www.researchgate.net/profile/Laszlo_Kajdi

Anna Sára Ligeti. Hungarian Central Statistical Office. Budapest, Hungary.

E-mail: Anna.Ligeti@ksh.hu

URL: https://www.ksh.hu/?lang=en 


\section{Comparative Population Studies}

WWW.comparativepopulationstudies.de

ISSN: 1869-8980 (Print) - 1869-8999 (Internet)

\section{Published by}

Prof. Dr. Norbert F. Schneider

Federal Institute for Population Research D-65180 Wiesbaden / Germany

\section{(cc) BY-SA}

2020

\section{Managing Editor}

Prof. Dr. Johannes Huinink

Dr. Katrin Schiefer

\section{Editorial Assistant}

Beatriz Feiler-Fuchs

Wiebke Hamann

\section{Layout}

Beatriz Feiler-Fuchs

E-mail:cpos@bib.bund.de

\section{Scientific Advisory Board}

Karsten Hank (Cologne)

Michaela Kreyenfeld (Berlin)

Marc Luy (Vienna)

Natalie Nitsche (Rostock)

Zsolt Spéder (Budapest)

Rainer Wehrhahn (Kiel)

\section{Board of Reviewers}

Bruno Arpino (Barcelona)

Kieron Barclay (Rostock)

Laura Bernardi (Lausanne)

Gabriele Doblhammer (Rostock)

Anette Eva Fasang (Berlin)

Michael Feldhaus (Oldenburg)

Tomas Frejka (Sanibel)

Alexia Fürnkranz-Prskawetz (Vienna)

Birgit Glorius (Chemnitz)

Fanny Janssen (Groningen)

Frank Kalter (Mannheim)

Stefanie Kley (Hamburg)

Bernhard Köppen (Koblenz)

Anne-Kristin Kuhnt (Duisburg)

Hill Kulu (St Andrews)

Nadja Milewski (Rostock)

Roland Rau (Rostock)

Thorsten Schneider (Leipzig)

Tomas Sobotka (Vienna)

Jeroen J. A. Spijker (Barcelona)

Heike Trappe (Rostock)

Helga de Valk (The Hague)

Sergi Vidal (Barcelona)

Michael Wagner (Cologne) 